\title{
Stage I Hypopharyngeal Squamous Cell Carcinoma AJCC v7
}

National Cancer Institute

\section{Source}

National Cancer Institute. Stage I Hypopharyngeal Squamous Cell Carcinoma A/CC v7. NCl Thesaurus. Code C8232.

Stage I includes: T1, N0, M0. T1: Tumor limited to one subsite of hypopharynx and/or 2 $\mathrm{cm}$ or less in greatest dimension. N0: No regional lymph node metastasis. M0: No distant metastasis. (AJCC 7th ed.) 